\title{
Proliferation of E-Newspapers and Its Financial Impact on the Publishing Industry in UAE
}

\author{
Jacob Cherian $^{1} \&$ Sherine Farouk ${ }^{2}$ \\ ${ }^{1}$ Department of Management, College of Business Administration, Abu Dhabi University, Abu Dhabi, UAE \\ ${ }^{2}$ Department of Accounting, College of Business Administration, Abu Dhabi University, Abu Dhabi, UAE \\ Correspondence: Jacob Poopada Cherian, Department of Management, College of Business Administration, Abu \\ Dhabi University, Abu Dhabi, UAE. Tel: 971-5-015-646. E-mail: jacob.cherian@adu.ac.ae
}

Received: January 4, 2015

doi:10.5539/ijef.v7n3p194

\begin{abstract}
Currently online news sites have greatly satisfied the expectations of the readers, and there has been a decrease in the circulation of print newspapers. Proliferation of various e newspapers has given a lot of choices to people so that there is a growing competition between the two. Here an attempt is made to gather all the available literature resources so that the research will enable the printing industry to think of moving in a different direction. As the world is moving fast in terms of technology the easiest option to save time and get the information via internet. The senior citizens still opt for the traditional form of newspapers. The development of multiple communication mediums such as the internet, smart phones or e-readers supports the UAE youngsters to get the news rapidly. It also provides the information up-to-date, faster by using internet technology. The online media impact on print media begins on the different views of print media such as print revenue, demand, market share, profitability, subscription and advertising revenue. The male students in UAE colleges prefer reading newspapers in online than the female. This research focuses on the qualitative study of the e newspapers advantage over the Print News papers.
\end{abstract}

Keywords: print media revenue, customer subscription, advertising revenue, market share, profit

\section{Introduction}

The digital era has profoundly changed the information delivery and communication system through the mediums like newspaper, radio, etc., which has enhanced the environmental stewardship for a sustainable growth. The changes caused by human activities seek to balance and integrate with sustainability's key factor, namely social, economic and environmental. Substantially, these changes have influenced the current newspaper industry (Veglis \& Pomportsis, 2004). Even though studies have stated that online advertisements have an positive effect than the newspaper ads (Van Duyn, 2007), but no concise evidence have been proved to attain the sustainable level (e.g., Nesbitt \& Lavine, 2004; Ernst, 2007; Lemberg, 2007; Pfanner, 2007; Albers, 2007; Kubas \& Kubas, 2007; Jones, 2007; Cohen, 2007). Hence, the current report aimed at identifying the factors that influence the proliferation of e-newspapers over the traditional newspapers in the UAE context by reviewing the previous studies conducted elsewhere.

\section{Research Objectives}

The major objective of this study is to collect analyze the data and study the literature related to Proliferation of E-Newspapers over the Traditional Newspapers in UAE. Following are the research objectives of the study.

1). Identify the preference for the type of newspapers and its reasons;

2). Examine the major reasons behind falling circulation and advertising revenues of the traditional newspapers;

3). Examine the impact of e-newspapers on traditional newspapers;

4). Identify possible suggestions to increase the demand for traditional newspapers.

\section{Literature Review}

In the global business world, around 90 percent of people in UAE are literates and majority of these individuals have reading habits via daily newspapers and periodical publications. With the advent of digital media and World 
Wide Web (WWW) a dynamic shift to the online platform is created, especially among the youths in UAE. News reading habit supports a never-ending tendency towards notifying a person's day-to-day activities and acts as information gathering system. Researches on perfunctory information seeking activities and news reading among the UAE youth depicted tremendous growth has been achieved from traditional to e-newspaper modes. Hence, the present section reviews the previous literature on sustainable development of e-newspapers from traditional newspapers among UAE Business firms. Especially it discusses about the factors which influence the e-newspapers habit among UAE individuals.

A preliminary survey was conducted by Cass (2001) of newspaper holdings and archives available from commercial, university and government archives in emirates of Abu Dhabi, Dubai and Sharjah. This study supports the detailed explanation of UAE press origin and correlated the existed newspapers effort to save the generation of Emirati publications. Further, this study showed that Arabs prefer traditional news paper over e-newspaper as majority are published in Arabic language. Since e-newspapers in general are published in English, native Arabs find difficult in reading these papers due to language barrier. However, few other outsiders arrived and settled in UAE preferred e-newspapers as their top most news reading.

Likewise the study by Alshehri (2000) examined the satisfaction level of Arab e-newspapers over the traditional newspaper. The study adopted triangulation methodology where both qualitative and quantitative design was adopted. The Arab journalists were interviewed while survey was conducted among the readers and publishers. From the study findings it was evident that majority of the traditional newspaper firms preferred the online medium instead of printed version. However, there was poor response because majority of the e-content were in the same format as of in printed version. However, despite their interest over publishing online, their strategy was identified to be poor and also no awareness about the importance to their traditional business activities. Moreover, study also showed that there was similar demographic profile among Arab and non-Arab enewspaper readers in which these demographic characterises include the education, age and occupation. The satisfaction level of e-readers was identified to be high than print media. Therefore, this study recommends it is essential for the Arabic print media to adopt appropriate online strategy and advanced techniques to achieve the sustainable position in online printing.

Sharma (2009) analysed the ratio of importance given to print media (National English Dailies) (Text) and Visuals (include graphics, pictures etc.) in two significant countries of Middle East region such as Oman Sultanate and UAE. Their study focused on the rapid development of electronic media and reduction of print media process. Both Primary and secondary sources are used in this study during the data collecting process. The study findings revealed that due to the advancement in the electronic media, the print media was experiencing a series of threat. In particular, these study findings revealed that the current competitive fast moving world has caused time limitation were readers needed the information via visuals and pictures than words. Therefore, this study has recommended that the print media has to adopt more attractive picture or visuals in order to attract current news readers. Further, print media applied the critical media analysis which is helpful for the sustainable growth of educators in the media, multinational company's policy makers, students of media studies and local government authorities.

Jacob (2011) examined the free Online Publications impact on Print Media. The study was conducted focusing on single Saudi's familiar firm, the Saudi Research and Publishing Company (SRPC), a leading publishing industry across the UAE. Their study observed the readership practice of SRPC staffs in online magazines and newspapers. The study findings revealed that there was no significant relation between the personal attributes and type of media. Majority of participants, irrespective of their educational background, age group and gender, they preferred the online media, especially the internet. However, citizens above 50 years preferred to read traditional newspapers due to the unawareness about the online media. Further, this study assured that there is no statistically significant relation between preference and the reasons for the media type. Moreover, this study has assured empirically the online resource diminish the print media. Some online media impacts on print media are print revenue, advertising revenue subscription, demand, profitability and market share.

Ayyad (2011) investigated the traditional media versus Internet usage among the university students at the University of Sharjah (UOS) in UAE. This study used the approach of 'uses and gratification' to describe in what way students are goal-oriented in usage of the Internet and mass media. A questionnaire included 21 questions was designed and examined by using the sample size of 270 UOS students. These 21 questions have covered the usage of the Internet and traditional media patterns such as newspapers, radio and television among students. Their study findings revealed that the exposure patterns to the new and mass media among the UOS students were mostly the Internet when compared to traditional media. Their results show that internet is widely used by almost all the students for different purposes. The effect of internet reflects as exposure of student in traditional 
media such as reading newspapers and watching TV. The gender preference was also observed were the study findings revealed that males prefer watching and browsing internet for watching TV and reading newspapers to obtain information and current affairs rather than females.

Wischenbart (2012) conducted the survey on reading habits and multimedia usage among UAE individuals. Data was collected from 503 interviews among the International Sharjah Book Fair visitors. Questionnaire was designed to cover personal background, questions relevant to reading habits of individuals includes the perception of readers among the online and print books, content analysis (context) as well as cultural practices of reading. Their results were correlated with numerous indicators, age, gender and reading education, etc. Further this study appreciates the UAE individuals because of their reading habit and also heavy competition was observed among the media. In online source, the different source of materials are viewed and searched within as short time rather than printed publications. The major factors that were observed in this study are the internet impact on reading habits and also competition between different groups. Further increase in the choice selection and accessibility of various materials in content wise has been improved with books. Thus leads to achieve the sustainable growth in traditional media.

Al-Shaqsi (2013) focused on the perception of readers and readership among the Omani newspapers in the current modern world. This study has evaluated attitudes and the reading habit of individuals to the layout and contents of various free weekly tabloids and nine newspapers. Based on the non-probability convenience sample selection, a survey was carried out on 747 subjects from Muscat, the Oman capital. Their findings reported that only $5.5 \%$ of the participants do not have the habit of reading newspapers. The main reason of avoiding the newspaper reading habit due to lack of time and using other media sources availability. Moreover the study observed that most of the readers of Omani newspapers are males with university and diploma degree holders who were working in the public sector. Therefore, readers have not much of time to read the newspaper in text format. Additionally, the study has observed the frequency of reading and has compared in the aspects of professionalism and content type more than the presentation (design \& layout) and the appearance of Omani newspapers.

Cherian and Jacob (2013) stated that the individual's enjoy reading both print and online news papers. Further, the study evaluated the choice of consumers in both online and print media regarding the format preference and demographics. Data collection was adopted by the study through the primary quantitative approach while the survey was carried out among the post graduate university students of 150 colleges. Their study finding noticed that the printed papers have the current choice, but it needs more advanced techniques in the preference viewpoint of respondents. Further, the present e-newspapers have formulated special techniques to attract the news readers and reduce the print circulation. Moreover, the young college going students are more interested in reading the news which become a habit in UAE. They require most advanced techniques in the modern world. Therefore this study suggested that the print publications need to develop some novel techniques for their sustainable practice.

The internet advent has changed the traditional trend of print publication. Satarupa (2014) analysed the online reading habits of UAE youth of 18 and 25 age group youths. This study focused on the analysis of youths' reading behaviour such as how to recognize the news and follow them and frequency in order to attain the conclusion of the news. In this study both quantitative and qualitative studies were conducted. Their study finding observed that the youths are recognized with the e-newspapers and are delivered as rapid and easily attained by the most preferable mediums like the internet, smart phones or e-readers by the way of giving information. This is an important factor for the youth to provide more preference to e-newspapers.

The report of Arab Youth Survey (2014) analysed attitudes of the Arab youth in the age group of 18-24 years at 16 countries includes the six Gulf States (Oman, Kuwait, the UAE, Bahrain, Saudi Arabia and Qatar) Lebanon, Egypt, Algeria, Iraq, Libya, Jordan, Morocco, Yemen, Palestine and Tunisia. There were 200 respondents for each country represented in the survey, except the UAE, Saudi Arabia, Egypt with 300 respondents each, and Iraq with 250 and Palestine with 150. This study finding reported that television was the mass media where the Arab youth obtained day-to-day information. At the same time, the influence of smart phones impacted the youngsters as to pursue the news in online. Therefore, the reduction of reading the traditional newspapers was observed. The study concluded that out of five, three of the youngsters (59\%) viewed online as their preferred choice of news. While out of ten, only three members viewed traditional newspapers to obtain information.

Alanazi (2014) analysed the usage of e-newspapers via smart phones among the Saudi Arabian students in the United States. Researcher collected the information from Face book page and Twitter account with the support of the Saudi Arabian Cultural Mission by distributing the Qualtrics survey technique. Consequently, the sample size 
of the study was observed to be 789 Saudi Arabian students in US. Further this study used non-probability convenience sample technique. Specifically, this study was used the Uses and Gratification Theory for the identification of usage of smart phones and also analysed the experience of students for using these phones as news reading habit. Data analysis was carried out by the participants who have the habit of checking the news frequently. Their study results revealed that the participants without using these phones felt that they were left alone and also overwhelmed by getting higher information from the short time. In addition the study findings described that the use of smart phones helped in sharing information through the social sites is an added advantage. Their finding concluded that the smart phones also increase the delivery of news through online and also support in achieving the sustainable growth.

According to the report of Booz and Co. company explored the status of print publication across the gulf region (Chahine, Molina, \& Sheikh, 2009). Their study findings reported that the print media publication attained the inflection point as a result the digital media gained more interest. Further this study analysed the print media migration and study findings identified the factors such as low of rich digital media content, low level of penetration in digital devices and issues in infrastructure included download speeds on fixed networks and low broadband capacity in companies of traditional media. Therefore, there is a necessity to improve the access of the digital source in print media publications to achieve the sustainable position.

From the empirical results it was evident that the factors like poor online strategy, no awareness about the importance of internet over traditional, no time due to the fast moving world, language barrier influence the proliferation of e-newspapers over the traditional newspapers in the UAE.

\section{Conclusion}

From the findings of several past studies in the UAE context, it is showed that the majority of them preferred the e-newspapers (herein referred to as online newspapers). In the current technological world, individuals have not much of time to read the news from text format, readers need to get the news from visual form, it takes only less time. From this reason, the print media has changes into more visual to attracting the audience. The only exception the senior citizens who are aged above 50 prefer the print media especially traditional newspapers. The development of multiple communication mediums such as the internet, smart phones or e-readers supports the UAE youngsters to get the news rapidly. It also provides the information up-to-date, faster by using internet technology. The online media impact on print media begins on the different views of print media such as print revenue, demand, market share, profitability, subscription and advertising revenue. The male students in UAE colleges prefer reading newspapers in online than the female. Due to the availability of internet communications, the students get information easily. Some of the major reasons concluded from this study is there is a lack of time to read newspapers and availability of other major communication resources. Majorly this e-news is considered as time consuming. Finally, the study concluded that the online news has highly satisfied the reader's expectations and also reduced the print news papers circulation. This is major reason of the proliferation of e-newspapers over the traditional newspapers in UAE.

\section{References}

Alanazi, A. D. (2014). The Use of the Smartphones As A Resource For News Among SaudI. Retrieved from https://dspace.iup.edu/bitstream/handle/2069/2132/Ali Dhumayan Alanazi.pdf?sequence=1

Albers, R. R. (2007). Turning the page. Press Time, 32-38.

Al-Shaqsi, O. S. (2013). Readership and Readers' Perception of Omani Newspapers. Global Media Journal, 12(22). Retrieved December $\quad 22, \quad$ from https://www.questia.com/library/journal/1P3-2978687091/readership-and-readers-perception-of-omani-new spapers

Alshehri, F. A. (2000). Electronic Newspapers On The Internet: A study of the production and consumption of Arab dailies on the World Wide Web. Thesis Submitted for the Degree of Doctor of Philosophy to the Department of Journalism Studies University of Sheffield. Retrieved December 22, 2014, from http://core.kmi.open.ac.uk/download/pdf/14343400.pdf

Arab, Y. S. (2014). We want to embrace modern values. ASDA'A Burson-Marsteller. Retrieved December 22 , 2014,

from http://arabyouthsurvey.com/wp-content/themes/arabyouth-english/downloads/AYS-Whitepaper-en.pdf

Ayyad, K. (2011). Internet usage vs traditional media usage among university students in the United Arab Emirates. Journal of Arab \& Muslim Media Research, 4(1), 41-61. http://dx.doi.org/10.1386/jammr.4.1.41_1 
Cass, P. (2001). Newspaper Archiving in the UAE: Australian Media Traditions Conference, 14-15 June, Yeppoon, Australia. Retrieved December 22, 2014, from http://hdl.handle.net/10652/2026.

Chahine, G., Molina, H., \& Sheikh, F. (2009). Connecting with GCC Consumers: CPG Marketing and Sales Executives Must Respond Strategically to New Buying Patterns. Booz \& Company. Retrieved from http://www.strategyand.pwc.com/global/home/what-we-think/reports-white-papers/article-display/connectin g-with-consumers-marketing-sales

Cherian, J., \& Jacob, J. (2013). Analysis of Attitude towards Online and Print Publications: A Case Study among University Students. Asian Social Science, 9(1). Retrieved December 22, 2014, from http://www.ccsenet.org/journal/index.php/ass/article/view/23531

Cohen, H. (2007). What 'time on site' means for online media. Retrieved December 22, 2014, from http://clickz.com

Ernst, H. (2007). At your readers' fingertips. Press Time, 42-46.

Jacob, C. (2011). Impact of Free Online Publications on Print Media. Advances In Management, 4(6). Retrieved December 22, 2014, from https://ideas.repec.org/a/mgn/journl/v4y2011i6a8.html

Jones, M. L. F. (2007). Segmentation, experimentation critical to building audiences. Press Time, 24.

Kubas, L., \& Kubas, C. (2007). Why creating demand for newspapers works better than managing supply. Retrieved December 22, 2014, from http://www.inma.org

Lemberg, J. (2007). Retail growth leads to single-copy sales opportunities. Press Time, 21-23.

Nesbitt, M., \& Lavine, J. (2004). Reaching new readers: Revolution, not evolution, Evanston. IL: Northwestern University Readership Institute.

Pfanner, E. (2007). Norwegian newspaper publisher finds the secret to profiting online. The International Herald Tribune. Retrieved December 22, 2014 from http://www.iht.com

Satarupa, M. B. (2014). Disseratation on Online Reading Habits in UAE Youth. Writing Wreck. Retrieved December 22, 2014, from https://satarupab7.wordpress.com/2014/11/02/disseratation-on-online-reading-habits-in-uae-youth/

Sharma, S. K. (2009). Critical Media Analysis: A Comparative Study of Print Media in Oman and UAE. Global Media Journal, 8(14). Retrieved December 22, 2014, from http://lass.purduecal.edu/cca/gmj/sp09/gmj-sp09-sharma.htm

Van Duyn, A. (2007). Online ads to overtake U.S. newspapers. Retrieved December 22, 2014, from https://FT.com

Veglis, A., \& Pomportsis, A. (2004). New production models for newspaper organizations 2 From Analogue to digital 3 Changing Production Models. Retrieved December 22, 2014, from http://www.wseas.us/e-library/conferences/cancun2004/papers/485-328.pdf

Wischenbart, R. (2011). Reading Habits in the United Arab Emirates:Report-Reading Habits in the UAE. A survey conducted among attendants of the Sharjah International Book Fair in November 2011, 1-19. Retrieved December 22, 2014, from https://editoriaraba.files.wordpress.com/2012/10/reading-habits-in-the-uae.pdf

\section{Copyrights}

Copyright for this article is retained by the author(s), with first publication rights granted to the journal.

This is an open-access article distributed under the terms and conditions of the Creative Commons Attribution license (http://creativecommons.org/licenses/by/3.0/). 